ISSN: 2302-8556

E-Jurnal Akuntansi Universitas Udayana

Vol.24.1.Juli (2018): 58-86

DOI: https://doi.org/10.24843/EJA.2018.v24.i01.p03

\title{
Reputasi Auditor Sebagai Pemoderasi Pengaruh Financial Distress dan Audit Fee Pada Auditor Switching
}

\author{
Putu Ayu Putri Sima ${ }^{1}$ \\ I Dewa Nyoman Badera ${ }^{2}$
}

${ }^{1}$ Fakultas Ekonomi dan Bisnis Universitas Udayana (Unud), Bali, Indonesia
email: simaputri@ yahoo.co.id / Telp: +6287862002293
${ }^{2}$ Fakultas Ekonomi dan Bisnis Universitas Udayana (Unud), Bali, Indonesia

\begin{abstract}
ABSTRAK
Auditor switching didefinisikan sebagai pergantian auditor atau Kantor Akuntan Publik (KAP) yang dilakukan oleh perusahaan. Variabel Independen dalam Penelitian ini adalah Financial Distres dan Audit Fee. Auditor Switching sebagai variabel dependen. Penelitian ini dilakukan pada perusahaan manufaktur yang terdaftar di Bursa Efek Indonesia (BEI) tahun 2012-2016. Jumlah perusahaan manufaktur yang terdaftar di BEI sebanyak 144 perusahaan dan diperoleh sampel penelitian sejumlah 25 perusahaan. Metode pengumpulan sampel yang digunakan adalah metode non probability sampling dengan teknik purposive sampling dan teknik analisis data yang digunakan adalah uji analisis deskriptif, analisis regresi logistik (logistic regression) dan Moderating Regression Analysis (MRA). Hasil pengujian hipotesis menunjukkan bahwa financial distress berpengaruh positif pada auditor switching sedangkan audit fee tidak berpengaruh pada auditor switching. Reputasi auditor tidak mampu memoderasi pengaruh financial distress dan audit fee pada auditor switching.
\end{abstract}

Kata kunci: Auditor switching, financial distress, audit fee, reputasi auditor

\section{ABSTRACT}

The switching auditor is defined as a change of auditor or Public Accounting Firm (KAP) conducted by the company. Independent variable in this research is Financial Distress and Audit Fee. Switching Auditor as the dependent variable. This study was performed on companies listed on the Stock Exchange from 2012-2016. The number of manufacturing companies listed on the BEI as many as 144 companies and obtained a sample of 25 companies. Sampling method used was non probability sampling method with purposive sampling technique and data analysis technique used was descriptive analysis test, logistic regression and Moderating regression analysis (MRA). The result of hypothesis testing shows that financial distress have positive effect on the switching auditor while audit fee has no effect on the switching auditor. The auditor's reputation is not able to moderate the influence of financial distress and audit fees on the switching auditor.

Keywords: Switching auditor, financial distress, audit fee, auditor reputation 


\section{PENDAHULUAN}

Laporan keuangan merupakan salah satu alat pertanggung jawaban manajemen kepada pemilik perusahaan. Laporan keuangan digunakan sebagai dasar dalam menentukan atau menilai posisi dan kegiatan operasional perusahaan. Laporan keuangan yang dikeluarkan oleh perusahaan memberikan informasi tentang kondisi keuangan perusahaan kepada pembaca laporan keuangan, sedangkan bagi pemilik perusahaan laporan keuangan merupakan sarana pertanggungjawaban manajemen atas pengelolaan sumber daya yang dimiliki perusahaan (Astrini, 2013). Kinerja manajemen dapat dilihat dalam laporan keuangan dan oleh karena itu untuk mengurangi potensi laporan keuangan dipengaruhi oleh kepentingan manajemen, maka diperlukan peran akuntan publik atau auditor sebagai pihak independen yang mampu menjembatani benturan kepentingan antara pemilik perusahaan dan manajemen.

Timbul dan berkembangnya suatu profesi akuntan publik sangat dipengaruhi oleh perkembangan perusahaan pada umumnya yang membutuhkan jasa audit. Semakin banyak perusahaan yang berdiri, semakin banyak pula jasa akuntan publik yang dibutuhkan. Oleh karena itu, Kantor Akuntan Publik (KAP) saling bersaing untuk mendapatkan klien dengan berusaha memberikan jasa audit sebaik mungkin (Utami, 2013).

Independensi auditor merupakan kunci utama untuk menilai kewajaran laporan keuangan. Auditor yang dapat mempertahankan independensinya maka kemungkinan kualitas audit menjadi lebih tinggi dan auditor tidak mudah terpengaruh oleh 
ISSN: 2302-8556

kepentingan klien. Hubungan kerja yang panjang antara auditor dengan klien bisa menyebabkan auditor memiliki kecenderungan kehilangan independensinya dan menjadi dasar dalam melakukan pergantian KAP. Auditor akan kehilangan independensinya apabila terjadi masa perikatan audit yang lama sehingga menyebabkan perusahaan merasa nyaman dengan hubungan yang telah terjalin selama ini antara auditor dengan pihak manajemen perusahaan. Dalam situasi ini auditor akan terikat secara emosional. Mautz dan Sharaf (1961) dalam Nasser et al. (2006) menyatakan bahwa hubungan yang panjang antara auditor dan klien bisa menyebabkan auditor memiliki kecenderungan kehilangan independensinya.

Skandal Enron dengan KAP Arthur Anderson di Amerika Serikat pada tahun 2001 merupakan fakta yang terjadi akibat hubungan auditor dan klien yang terjalin lama. KAP Arthur Anderson sebagai salah satu KAP besar yang masuk dalam jajaran lima KAP terbesar di dunia atau Big Five. Kecurangan yang dilakukan oleh kliennya Enron melibatkan KAP Arthur Anderson sehingga gagal mempertahankan independensinya. Fakta ini menjadikan alasan bagi perusahaan untuk melakukan auditor switching.

Indonesia merupakan salah satu negara yang melakukan penerapan auditor switching secara wajib. Kewajiban mengenai rotasi auditor telah diatur oleh pemerintah dengan dikeluarkannya Peraturan Menteri Keuangan Republik Indonesia Nomor 17/PMK.01/2008 tentang “Jasa Akuntan Publik". Peraturan ini berisi tentang pemberian jasa audit umum atas laporan keuangan dari suatu entitas dapat dilakukan oleh Kantor Akuntan Publik (KAP) paling lama untuk 6 (enam) tahun buku berturut- 
turut dan oleh seorang Akuntan Publik paling lama untuk 3 (tiga) tahun buku berturut-turut. Kantor Akuntan Publik (KAP) dan Akuntan Publik dapat menerima kembali penugasan audit setelah 1 (satu) tahun buku tidak memberikan jasa audit umum atas laporan keuangan klien yang sama.

Karena adanya kewajiban rotasi auditor tersebut, sehingga timbul perilaku perusahaan untuk melakukan auditor switching. Auditor switching didefinisikan sebagai pergantian auditor atau Kantor Akuntan Publik (KAP) yang dilakukan oleh perusahaan.

Akan tetapi, perusahaan dalam melakukan pergantian KAP dapat terjadi oleh dua alasan yakni karena adanya peraturan pemerintah yang bersifat wajib (mandatory) dan dilakukan atas keinginan perusahaan itu sendiri, maka pergantian ini bersifat sukarela (voluntary). Apabila perusahaan mengganti KAP yang telah mengaudit selama masa yang ditentukan (6 tahun) merupakan hal yang wajar dan perusahaan melakukan hal tersebut dikarenakan ingin mematuhi aturan yang berlaku. Jika terjadi pergantian KAP oleh perusahaan yang dilakukan berdasarkan keinginan dari perusahaan sendiri, diluar peraturan yang ada, dan bersifat voluntary maka hal tersebut menimbulkan pertanyaan bahkan kecurigaan dari investor sehingga penting untuk diketahui faktor penyebabnya.

Keputusan untuk mengganti KAP secara voluntary menarik untuk diteliti karena banyak faktor yang dapat melatarbelakangi keputusan perusahaan untuk melakukan pergantian KAP atau auditor. Ketidakpastian dalam bisnis pada perusahaan yang terancam bangkrut (mempunyai kesulitan keuangan) yang diawali 
ISSN: 2302-8556

dari kesulitan yang ringan sampai keadaan yang lebih serius dapat mempengaruhi perusahaan tersebut untuk mengganti auditor dengan alasan keuangan. Kesulitan keuangan adalah kondisi perusahaan tidak mampu memenuhi kewajiban finansialnya. Harum (2017) menyatakan bahwa perusahaan yang mempunyai kesulitan keuangan lebih cenderung mengalami ketidakmampuan dalam membayar biaya audit.

Kondisi perusahaan yang memburuk membuat perusahaan tidak mampu dalam membayar fee audit. Audit fee merupakan salah satu penyebab terjadinya pergantian auditor. Audit fee merupakan imbalan atau fee yang diterima auditor setelah melaksanakan jasa auditnya. Schwartz dan Menon (1985) menyatakan bahwa hal yang mendorong perusahaan melakukan pergantian auditor dapat disebabkan oleh fee audit yang relatif tinggi sehingga tidak terjadi kesepakatan kedua belah pihak mengenai besar fee audit tersebut yang menyebabkan perusahaan melakukan pergantian auditor. Perusahaan yang mengalami kesulitan keuangan (financial distress) cenderung mengalami ketidakmampuan dalam membayar audit fee yang terlalu tinggi sehingga menimbulkan kondisi untuk melakukan auditor switching. Menurut Mulyadi (2002) besarnya fee audit dapat bervariasi tergantung pada kompleksitas jasa yang diberikan, risiko penugasan, tingkat keahlian yang diberikan untuk menjalankan penugasan tersebut, struktur biaya kantor akuntan publik yang bersangkutan dan pertimbangan profesional lainnya.

Penelitian-penelitian sebelumnya menunjukkan hasil yang tidak konsisten mengenai pengaruh audit fee terhadap auditor switching. Penelitian sebelumnya yaitu penelitian yang dilakukan Astuti (2014), Pradhana (2015) menunjukkan bahwa audit 
fee berpengaruh positif pada pergantian auditor. Penelitian yang dilakukan Ismail et al. (2008) juga mengungkapkan audit fee berpengaruh terhadap pergantian KAP, sedangkan penelitian yang dilakukan oleh Chadegani et al. (2011), Feng dan Riswan (2013) menemukan bahwa audit fee tidak berpengaruh terhadap auditor switching. Hasil penelitian Lestari (2012) dan Arinta (2013) juga mendapatkan hasil yang bertolak belakang dan menyatakan bahwa besarnya audit fee tidak berpengaruh terhadap keputusan perusahaan dalam melakukan pergantian auditor.

Rudyawan dalam Mahantara (2013) menyatakan Reputasi auditor merupakan prestasi dan kepercayaan publik yang disandang auditor atas nama besar yang dimiliki auditor tersebut. Investor akan lebih cenderung percaya pada data akuntansi yang dihasilkan oleh auditor yang bereputasi. Dengan mengganti KAP lama dengan KAP yang lebih memiliki nama, maka diharapkan reputasi perusahaan juga akan ikut terangkat di mata investor (Sinarwati, 2010). Reputasi auditor sangat menentukan kredibilitas (kualitas, kapabilitas, atau kekuatan untuk menimbulkan kepercayaan) dalam suatu laporan keuangan. Perusahaan akan mencari KAP yang kredibilitasnya tinggi untuk meningkatkan kredibilitas laporan keuangan di mata pemakai laporan keuangan itu (Halim, 1997).

Penggunaan reputasi auditor sebagai variabel moderasi karena auditor yang bereputasi baik memiliki keahlian audit yang lebih tinggi dan akan menghasilkan kualitas audit yang lebih baik pula dengan begitu perusahaan dapat menarik calon investor sehingga kepercayaan masyarakat terhadap perusahaan akan meningkat (Nasser et al., 2006). Perusahaan yang bekerja sama dengan KAP yang bereputasi 
ISSN: 2302-8556

baik tidak akan mengganti KAP tersebut. Audit fee KAP Big 4 lebih tinggi dibandingkan non Big 4. Dalam hal ini perusahaan yang telah menggunakan KAP bereputasi akan selalu menggunakan KAP bereputasi untuk mengaudit laporan keuangan perusahaan walaupun fee yang ditawarkan cukup tinggi. Berdasarkan pemaparan, maka penelitian ini mengangkat judul "Reputasi Auditor sebagai Pemoderasi Pengaruh Financial Distress dan Audit Fee pada Auditor Switching "

Financial distress menunjukkan bahwa kondisi di mana perusahaan mengalami kondisi yang tidak sehat ataupun kesulitan dalam keuangan sehingga dikhawatirkan akan mengalami kebangkrutan. Perusahaan yang mengalami kesulitan keuangan lebih cenderung mendapat respon negatif dari para investor sehingga investor kurang percaya terhadap profitabilitas perusahaan.

Menurut Schwartz dan Menon, Hudaib dan Cooke (dikutip dari Chadegani et al, 2011), perusahaan yang mengalami financial distress lebih cenderung untuk mengganti KAP mereka dibandingkan dengan perusahaan lain yang lebih sehat dengan alasan bahwa perusahaan perlu menyewa kualitas auditor yang lebih tinggi dibandingkan dengan sebelumnya untuk menarik kepercayaan stakeholders dan menambah kepercayaan diri perusahaan. Auditor switching ini juga dapat disebabkan karena perusahaan tidak dapat memenuhi biaya audit yang dibebankan oleh KAP yang mengauditnya dikarenakan perusahaan sedang mengalami kondisi keuangan yang menurun (Sulistiarini dan Sudarno, 2012).

Penelitian yang dilakukan Eka Aprilia (2012), Yasmin (2013) yang mendapatkan hasil bahwa perusahaan yang mengalami financial distress memiliki 
dorongan yang kuat untuk berpindah auditor daripada perusahaan yang tidak mengalami financial distress. Berdasarkan uraian diatas maka dapat dirumuskan hipotesis penelitian sebagai berikut:

$\mathrm{H}_{1} \quad$ : Financial distress berpengaruh positif pada auditor switching.

Dorongan untuk berpindah KAP dapat disebabkan oleh fee audit yang relatif tinggi yang ditawarkan oleh suatu KAP pada perusahaan sehingga tidak tercapainya kesepakatan antara perusahaan dengan KAP dan dapat mendorong perusahaan untuk melakukan auditor switching. Dalam hal ini untuk mengurangi biaya agensi maka manajemen akan memilih KAP yang menawarkan fee audit yang rendah. Chadegani et al (2011) menyatakan bahwa ketika manajer merasa tidak sesuai atau tidak nyaman dengan fee audit mereka, maka pihak manajer mencoba untuk melakukan pergantian KAP dengan harapan manajer memperoleh auditor yang sesuai dengan fee audit yang mereka tawarkan.

Penelitian yang dilakukan dilakukan Astuti (2014) membuktikan bahwa audit fee berpengaruh positif terhadap pergantian auditor. Hasil penelitian tersebut didukung juga dengan penelitian yang dilakukan Damayanti dan Sudarma (2007), Aditya Bayu (2015) membuktikan bahwa audit fee memiliki pengaruh yang signifikan pada pergantian auditor.

$\mathrm{H}_{2} \quad$ : Auditfee berpengaruh positif pada auditor switching.

Penelitian Mardiyah (2002) menunjukkan hasil yang positif signifikan bahwa reputasi auditor mempengaruhi auditor switching namun berbeda hasilnya dengan penelitian yang dilakukan oleh Sinarwati (2010) dan Santi Rahayu (2012) 
ISSN: 2302-8556

menunjukkan bahwa reputasi auditor tidak mempengaruhi manajemen berganti auditor.

Faktor yang menyebabkan auditor switching adalah kesulitan keuangan yang dihadapi suatu perusahaan. Perusahaan lebih memilih untuk berpindah auditor ketika mengalami financial distress. Menurut Schwartz dan Soo (1995) menyatakan bahwa perusahaan yang bangkrut lebih sering berpindah auditor daripada perusahaan yang tidak mengalami bangkrut. Dengan mengganti auditornya dengan auditor yang lebih mempunyai nama maka reputasi perusahaan juga akan terangkat dimata investor (Smith dan Nichols, 1982).

Hal tersebut dapat menjelaskan bahwa reputasi auditor mempengaruhi hubungan antara financial distress dan auditor switching. Berdasarkan uraian diatas maka dapat dirumuskan hipotesis penelitian sebagai berikut:

$\mathrm{H}_{3} \quad$ : Reputasi Auditor memperkuat pengaruh financial distress pada auditor switching.

Perusahaan tidak akan mengganti auditor apabila telah menggunakan jasa KAP yang bereputasi (Big 4) karena dapat mendukung perkembangan perusahaan dalam mempertahankan kelangsungan hidup perusahaan. Craswell et al. (1998) menyatakan bahwa auditor yang berasal dari KAP besar dan yang memiliki afiliasi dengan KAP internasional akan memiliki kualitas yang lebih tinggi karena auditor tersebut memiliki karakteristik yang dapat dikaitkan dengan kualitas seperti pelatihan, dan pengakuan internasional.

Perusahaan yang melakukan auditor switching tentunya mengharapkan reaksi positif. Oleh karena itu, dengan mengganti auditor lama dengan auditor yang lebih 
bereputasi maka secara tidak langsung nama baik perusahaan juga akan terangkat. Hasil penelitian yang dilakukan Nasser et al.,(2006) yang menyatakan bahwa perusahaan yang telah menggunakan jasa auditor yang berafiliasi dengan KAP big four biasanya akan puas dengan hasil kinerja auditnya dan tidak akan melakukan auditor switching dibandingkan dengan perusahaan yang tidak menggunakan KAP yang tidak berafiliasi dengan KAP big four. Untuk itu jika perusahaan telah menggunakan jasa KAP yang bereputasi atau sudah diaudit oleh KAP big four maka cenderung akan mempertahankan KAP big four daripada KAP non big four (Nabila 2010). Auditor yang berkualitas atau auditor yang berasal dari Kantor Akuntan Publik (KAP) yang memiliki skala besar (Big 4) akan mengenakan audit fee yang lebih tinggi pula, karena auditor yang berkualitas memiliki keahlian audit yang lebih tinggi dan cenderung lebih cepat menyelesaikan laporan auditannya (Dong Yu, 2007). Perusahaan akan mengganti auditornya dengan auditor lain ketika audit fee yang telah dibayarkan tersebut tidak sesuai dengan kualitas audit yang dihasilkan. Apabila perusahaan telah menggunakan KAP bereputasi dan dapat meningkatkan nama baik perusahaan, maka perusahaan akan selalu menggunakan KAP bereputasi untuk mengaudit laporan keuangan perusahaan walaupun fee yang ditawarkan cukup tinggi.

Gamal (2012) membuktikan bahwa perusahaan-perusahaan besar yang berada di Lebanon lebih cenderung akan memilih untuk membayar biaya audit yang tinggi dengan alasan mereka ingin mencari auditor dalam Kantor Akuntan Publik (KAP) yang memiliki reputasi baik sehingga dapat menghasilkan laporan audit yang berkualitas. 
ISSN: 2302-8556

E-Jurnal Akuntansi Universitas Udayana

Vol.24.1.Juli (2018): 58-86

$\mathrm{H}_{4} \quad$ : Reputasi auditor memperlemah pengaruh audit fee pada auditor switching.

\section{METODE PENELITIAN}

Penelitian ini adalah penelitian kuantitatif yang berbentuk asosiatif dimana penelitian ini lebih menekankan pada pengujian teori melalui pengukuran variabel penelitian dengan angka serta data dianalisis menggunakan prosedur statistik (Indriantoro dan Supomo, 2013:12). Sedangkan penelitian asosiatif yaitu penelitian yang bertujuan untuk mengetahui hubungan antara dua variabel atau lebih (Sugiyono, 2013:13). Pada penelitian ini, variabel yang digunakan adalah financial distress dan audit fee sebagai variabel independen, auditor switching sebagai variabel dependen dan reputasi auditor sebagai variabel moderasi. Sampel yang digunakan dalam penelitian ini diambil dengan menggunakan Metode purposive sampling, yaitu metode penentuan sampel dengan pertimbangan tertentu, dimana anggota sampel akan dipilih sedemikian rupa sehingga sampel yang dibentuk dapat mewakili sifat-sifat populasi (Sugiyono, 2017: 85). Kriteria untuk penentuan sampel pada penelitian ini adalah 1). Perusahaan manufaktur yang terdaftar di BEI pada tahun 2012-2016; 2). Perusahaan melakukan pergantian KAP pada tahun 2012-2016; 3). Perusahaan manufaktur yang menyediakan informasi keuangan secara lengkap selama tahun 2012-2016; 4). Perusahaan menggunakan laporan keuangan tahunan yang berakhir 31 desember dan perusahaan telah diaudit oleh auditor independen tahun 2012-2016 (dalam rupiah).

Teknik analisis data yang digunakan pada penelitian ini adalah analisis regresi logistik (logistic-regresion). Penelitian ini menggunakan teknik regresi logistik karena variabel terikat dalam penelitian ini menggunakan variabel dummy. Analisis 
regresi logistik digunakan untuk menguji apakah probabilitas terjadinya variabel terikat dapat diprediksi dengan variabel bebasnya. Penelitian ini juga menggunakan variabel moderasi. Variabel moderasi nantinya akan membuktikan apakah akan memperkuat atau memperlemah hubungan antara variabel independen dan dependen.

\section{HASIL DAN PEMBAHASAN}

Statistik deskriptif bertujuan untuk memberikan gambaran atau deskripsi tentang variabel-variabel penelitian dari suatu data yang mencakup jumlah sampel, nilai ratarata (mean), nilai maksimum, nilai minimum, dan standar deviasi dari masing-masing variabel. Hasil pengujian statistik deskriptif disajikan dalam Tabel 1.

\section{Tabel 1.}

Hasil Statistik Deskriptif

\begin{tabular}{lrrrrr}
\hline & N & Minimum & Maximum & Mean & \multicolumn{1}{c}{$\begin{array}{c}\text { Std. } \\
\text { Deviation }\end{array}$} \\
\hline FD & 125 & $-30,5980$ & 17,1214 &, 500565 & 4,2185482 \\
AF & 125 & 17,2396 & 26,0738 & 21,41062 & 1,5816221 \\
& & & & 6 & \\
RA & 125 &, 00 & 1,00 &, 1520 &, 36047 \\
AS & 125 &, 00 & 1,00 &, 3200 &, 46835 \\
FD_RA & 125 & $-8,3383$ & 13,2077 &, 145819 & 1,5563275 \\
AF_RA & 125 &, 0000 & 26,0738 & 3,608358 & 8,5720952 \\
Valid N (listwise) & 125 & & & & \\
\hline Sumber: Data diolath & & & & &
\end{tabular}

Sumber: Data diolah, 2017

Nilai minimum variabel financial distress (FD) sebesar -30,5980, nilai maksimum sebesar 17,1214 . Nilai minimum sesuai dengan tabulasi data perusahaan Apac Citra Centertex Tbk tahun 2012 dan nilai maksimum sesuai dengan tabulasi data perusahaan Pelangi Indah Canindo Tbk tahun 2014. Standar deviasi sebesar 4,2185482 dan nilai rata-rata (mean) sebesar 0,500565. Nilai mean sebesar 0,500565 
ISSN: 2302-8556

menunjukkan bahwa terdapat lebih banyak perusahaan yang mengalami financial distress daripada perusahaan yang tidak mengalami financial distress.

Nilai minimum variabel audit fee (AF) sebesar 17,2396, nilai maksimum sebesar 26,0738. Nilai minimum sesuai dengan tabulasi data perusahaan Nusantara Inti Corpora Tbk tahun 2012 dan nilai maksimum sesuai dengan tabulasi data perusahaan Unilever Indonesia Tbk tahun 2016. Standar deviasi sebesar 1,5816221 dan nilai rata-rata (mean) sebesar 21,410626. Nilai mean sebesar 21,410626 menunjukkan bahwa terdapat auditfee yang dibayarkan oleh perusahaan tinggi.

Nilai minimum variabel reputasi auditor (RA) sebesar 0, nilai maksimum sebesar 1. Nilai minimum sesuai dengan tabulasi data dimana perusahaan yang memiliki reputasi auditor 0 sebanyak 106 dan perusahaan yang memiliki nilai maksimum 1 sebanyak 19. Standar deviasi sebesar 0,36047 dan nilai rata-rata (mean) sebesar 0,1520. Nilai mean sebesar 0,1520 menunjukkan bahwa perusahaan yang menggunakan KAP yang berafiliasi dengan Big 4 lebih sedikit dibandingkan dengan perusahaan yang menggunakan KAP non Big 4.

Nilai minimum variabel auditor switching (AS) sebesar 0, nilai maksimum sebesar 1. Nilai minimum sesuai dengan tabulasi data dimana perusahaan yang terdapat auditor switching 0 sebanyak 86 dan perusahaan yang memiliki nilai maksimum 1 sebanyak 39. Standar deviasi sebesar 0,46835 dan nilai rata-rata (mean) sebesar 0,3200. Nilai mean sebesar 0,3200 menunjukkan bahwa perusahaan yang melakukan auditor switching lebih sedikit dibandingkan dengan perusahaan yang tidak melakukan auditor switching. 
Teknik pengujian hipotesis pada penelitian ini menggunakan regresi logistik (logistic regression). Penggunaan alat analisis regresi logistik adalah larena variabel dependen yaitu auditor switching bersifat dikotomi (melakukan pergantian KAP dan tidak melakukan pergantian KAP). Regresi logistik digunakan untuk menguji apakah probabilitas terjadinya variabel terikat dapat diprediksi dengan variabel bebasnya (Ghozali, 2011). Teknik analisis regresi logistik tidak memerlukan asumsi normalitas data pada variabel bebasnya (Ghozali, 2011) dan mengabaikan heteroskedastisitas (Gujarati, 2003).

Pengujian ini dilakukan untuk menguji hipotesis nol bahwa data empiris cocok atau sesuai dengan model. Kelayakan model regresi dinilai dengan menggunakan uji Hosmer and Lemeshow's Goodness of Fit Test. Jika nilai statistik uji Hosmer and Lemeshow's Goodness of Fit Test lebih besar dari 0,05 maka hipotesis nol diterima dan berarti model mampu memprediksi nilai observasinya atau dapatt dikatakan model dapat diterima karena cocok dengan data observasinya. Berikut disajikan tabel uji Hosmer and Lemeshow's Goodness of Fit Test.

\section{Tabel 2.}

\begin{tabular}{l}
\multicolumn{4}{c}{ Hasil Uji Hosmer and Lemeshow's } \\
\begin{tabular}{rrrrr}
\hline Step & Chi-square & Df & \multicolumn{1}{c}{ Sig. } \\
\hline 1 & 4,742 & 8 &, 785 \\
\hline Sumber: & Data diolah, 2017 & & \\
\hline
\end{tabular}
\end{tabular}

Dari tabel uji Hosmer and Lemeshow di atas dapat dilihat bahwa nilai signifikansi uji Hosmer and Lemeshow yaitu sebesar 0,785 yang lebih besar dari 0,05 maka hipotesis nol diterima dan berarti model mampu memprediksi nilai 
ISSN: 2302-8556

observasinya atau dapat dikatakan model dapat diterima karena cocok dengan data observasinya.

Pengujian ini dilakukan untuk mengetahui apakah keseluruhan model sesuai dengan data. Pengujian dilakukan dengan membandingkan nilai antara -2 Loglikehood (-2LL) pada awal (Block Number $=0$ ) dengan nilai -2 Log Likelihood (2LL) pada akhir (Block Number $=1)$. Apabila terdapat penurunan nilai Likelihood, ini menunjukkan model regresi yang baik atau dengan kata lain model yang dihipotesiskan fit dengan data.

\section{Tabel 3.}

Perbandingan nilai -2LL Awal dengan -2LL Akhir

\begin{tabular}{cc}
\hline -2LL awal (Block Number $=0)$ & 156,717 \\
\hline -2LL akhir (Block Number $=1)$ & 121,112
\end{tabular}

Sumber: Data diolah, 2017

Nilai -2LL awal sebesar 156,717 dan nilai -2LL akhir sebesar 121,112. Penurunan nilai -2LL ini menunjukkan bahwa model regresi yang baik atau dengan kata lain model yang dihipotesiskan fit dengan data.

Besarnya nilai koefisien determinasi pada model regresi logistik ditunjukkan dengan nilai Nagelkerke's $R$ Square. Nilai Nagelkerke's $R$ Square adalah variabilitas variabel tetap yang dapat dijelaskan oleh variabel bebas, sedangkan sisanya dijelaskan oleh variabel-variabel lain di luar penelitian. Nagelkerke's $R$ Square ini digunakan untuk mengukur seberapa besar variabel bebas yang digunakan dalam penelitian ini yaitu financial distress dan audit fee mampu mempengaruhi variabel terikat auditor switching. Berikut hasil pengujian pada Tabel 4. 
Tabel 4.

Hasil Uji Koefisien Determinasi (Nagelkerker's R Square)

\begin{tabular}{lrrr}
\hline Step & $\mathbf{- 2} \mathbf{L}$ Log likelihood & $\begin{array}{c}\text { Cox \& Snell R } \\
\text { Square }\end{array}$ & $\begin{array}{c}\text { Nagelkerke R } \\
\text { Square }\end{array}$ \\
\hline 1 & $121,112^{\mathrm{a}}$ &, 248 &, 347 \\
\hline Sumber: & Data diolah, 2017 & &
\end{tabular}

Berdasarkan Tabel 4 menunjukkan bahwa Nagelkerke's R Square sebesar 0,347 atau sama dengan $34,7 \%$. Hal ini berarti variabel bebas yang digunakan dalam penelitian ini yaitu financial distress dan audit fee mempengaruhi variabel terikat auditor switching sebesar 34,7\% sedangkan 65,3\% dipengaruhi oleh variabel lain di luar penelitian ini.

Matriks klasifikasi menunjukkan kekuatan prediksi dari model regresi untuk memprediksi auditor switching yang dilakukan oleh perusahaan. Berikut ini hasil uji matrik klasifikasi yang disajikan dalam Tabel 4.6

Tabel 5. Matrik Klasifikasi

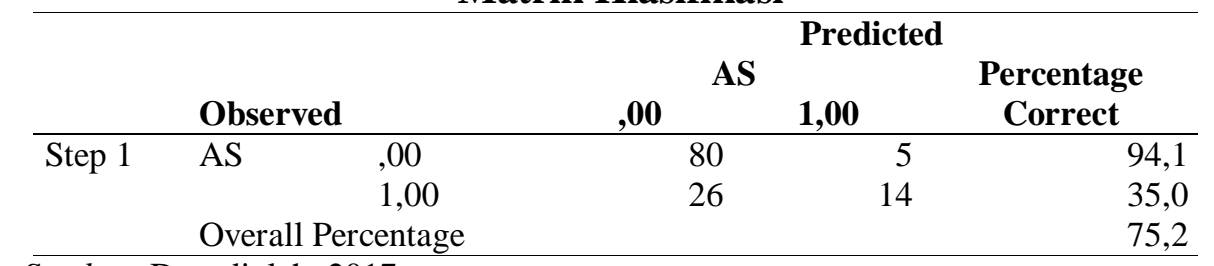

Sumber: Data diolah, 2017

Berdasarkan Tabel 5 kemampuan memprediksi model regresi untuk kemungkinan perusahaan melakukan auditor switching adalah sebesar 35\%. Sehingga dapat diketahui bahwa dengan menggunakan model regresi tersebut, terdapat sebanyak 14 perusahaan atau 35\% yang diprediksi akan melakukan auditor switching dari total 40 perusahaan yang melakukan auditor switching. Sedangkan kemampuan memprediksi model regresi untuk kemungkinan perusahaan tidak 
ISSN: 2302-8556

melakukan auditor switching adalah sebesar 94,1\%. Sehingga dapat diketahui bahwa dengan menggunakan model regresi tersebut, terdapat sebanyak 80 perusahaan atau 94,1\% yang diprediksi tidak melakukan auditor switching dari total 85 perusahaan yang tidak melakukan auditor switching. Nilai koefisien regresi dan signifikansi ditunjukkan dari model regresi yang terbentuk. Berikut ini hasil pengujian model regresi yang terbentuk disajikan dalam Tabel 6

Tabel 6.

Hasil Uji Regresi Logistik

\begin{tabular}{|c|c|c|c|c|c|c|c|}
\hline \multirow{2}{*}{ Step $1^{\mathrm{a}}$} & & B & S.E. & Wald & Df & Sig. & $\operatorname{Exp}(B)$ \\
\hline & FD & 1,004 & ,356 & 7,960 & 1 &, 005 & 2,730 \\
\hline & $\mathrm{AF}$ &, 157 & 208 &, 572 & 1 & ,449 & 1,170 \\
\hline & RA & $-13,812$ & 24,090 & ,329 & 1 & ,566 &, 000 \\
\hline & FD_RA & 12,530 & 13,362 & ,879 & 1 & ,348 & 276380,243 \\
\hline & AF_RA & ,339 & ,799 &, 180 & 1 & 671 & 1,404 \\
\hline & Constant & $-5,201$ & 4,446 & 1,368 & 1 & ,242 & ,006 \\
\hline
\end{tabular}

Berdasarkan Tabel 6. maka model regresi yang terbentuk adalah sebagai berikut:

$$
\begin{aligned}
\operatorname{Ln} \frac{\mathrm{P}(\mathrm{AS})}{1-\mathrm{P}(\mathrm{AS})} & =-5,201+1,004 \mathrm{FD}+0,157 \mathrm{AF}-13,812 \mathrm{RA}+12,530 \mathrm{FD} * \mathrm{RA} \\
& +0,339 \mathrm{AF} * \mathrm{RA}+\mathrm{\varepsilon i}
\end{aligned}
$$

Berdasarkan model regresi yang terbentuk, dapat diinterpretasikan hasil sebagai berikut: 1). Nilai konstanta sebesar -5,201 yang berarti apabila semua variabel independen bernilai konstan sama dengan nol, maka kecenderungan auditor switching sebesar -5,201; 2). Koefisien regresi variabel financial distress sebesar 1,004 yang berarti setiap peningkatan financial distress, dengan asumsi variabel lainnya dianggap konstan, maka kecenderungan auditor switching yang dilakukan perusahaan meningkat. Berdasarkan nilai koefisien regresi yang bernilai positif sebesar 1,004 serta nilai signifikan diperoleh nilai sebesar $0,005<0,05$, sehingga 
financial distress berpengaruh positif pada auditor switching; 3). Koefisen regresi variabel audit fee sebesar 0,157 yang berarti setiap peningkatan audit fee, dengan asumsi variabel bebas lainnya dianggap konstan, maka kecenderungan auditor switching yang dilakukan perusahaan meningkat.

Berdasarkan nilai koefisien regresi yang bernilai positif sebesar 0,157 dengan nilai signifikan diperoleh nilai sebesar 0,449 >0,05, sehingga audit fee tidak berpengaruh pada auditor switching; 4). Koefisien regresi variabel reputasi auditor sebesar $-13,812$ yang berarti apabila reputasi auditor naik, dengan asumsi variabel bebas lainnya dianggap konstan, maka kecenderungan auditor switching yang dilakukan perusahaan menurun; 5). Koefisien regresi variabel interaksi antara variabel financial distress dengan variabel reputasi auditor menunjukkan nilai koefisien bernilai positif sebesar 12,530 dengan nilai signifikansi $(0,348>0,05)$. Hasil tersebut menunjukkan bahwa reputasi auditor tidak dapat memoderasi pengaruh financial distress pada auditor switching; 6). Koefisien regresi variabel interaksi antara variabel audit fee dengan variabel reputasi auditor menunjukkan nilai koefisien bernilai positif sebesar 0,339 dengan nilai signifikansi $(0,671>0,05)$. Hasil tersebut menunjukkan bahwa reputasi auditor tidak dapat memoderasi pengaruh audit fee pada auditor switching.

Hipotesis pertama menyatakan bahwa variabel financial distress berpengaruh positif pada auditor switching. Hasil pengujian menunjukkan bahwa koefisien regresi positif sebesar 1,004 dengan tingkat signifikansi 0,005 yang berarti lebih kecil dari $0,05(\alpha=5 \%)$. Hal ini menunjukkan bahwa $\mathrm{H}_{0}$ ditolak dan $\mathrm{H}_{1}$ diterima. Sehingga 
ISSN: 2302-8556

E-Jurnal Akuntansi Universitas Udayana

Vol.24.1.Juli (2018): 58-86

dapat disimpulkan bahwa variabel financial distress berpengaruh positif pada auditor switching.

Hipotesis kedua menyatakan bahwa variabel audit fee berpengaruh positif pada auditor switching. Hasil pengujian menunjukkan bahwa koefisien regresi positif sebesar 1,004 dengan tingkat signifikansi 0,449 yang berarti lebih besar dari 0,05 $(\alpha=$ 5\%). Hal ini menunjukkan bahwa $\mathrm{H}_{0}$ diterima dan $\mathrm{H}_{2}$ ditolak. Sehingga dapat disimpulkan bahwa variabel audit fee tidak berpengaruh pada auditor switching. Hipotesis ketiga menyatakan bahwa variabel reputasi auditor memoderasi pengaruh financial distress pada auditor switching. Hasil pengujian menunjukkan bahwa koefisien regresi positif sebesar 12,580 dengan tingkat signifikansi 0,348 yang berarti lebih besar dari $0,05(\alpha=5 \%)$. Hal ini menunjukkan bahwa $\mathrm{H}_{0}$ diterima dan $\mathrm{H}_{3}$ ditolak. Sehingga dapat disimpulkan bahwa reputasi auditor tidak dapat memoderasi pengaruh financial distress pada auditor switching.

Hipotesis keempat menyatakan bahwa variabel reputasi auditor memoderasi pengaruh audit fee pada auditor switching. Hasil pengujian menunjukkan bahwa koefisien regresi positif sebesar 0,339 dengan tingkat signifikansi 0,671 yang berarti lebih besar dari $0,05(\alpha=5 \%)$. Hal ini menunjukkan bahwa $\mathrm{H}_{0}$ diterima dan $\mathrm{H}_{4}$ ditolak. Sehingga dapat disimpulkan bahwa reputasi auditor tidak dapat memoderasi pengaruh audit fee pada auditor switching.

Hasil pengujian dengan menggunakan regresi logistik menunjukkan nilai koefisien positif sebesar 1,004 dengan tingkat signifikansi sebesar 0,005 yang lebih kecil dari $\alpha=5 \%(0,005<0,05)$. Hal ini menunjukkan bahwa variabel financial 
distress berpengaruh positif pada auditor switching dengan kata lain $\mathrm{H}_{1}$ diterima. Hal ini menunjukkan bahwa jika suatu perusahaan mengalami kesulitan keuangan maka akan mengakibatkan perusahaan melakukan pergantian KAP. Hasil penelitian ini sesuai dengan hasil penelitian yang dilakukan Alexandros dan Dewi Murdiawati (2015), Dwijayanti (2014), dan Yasmin (2013) yang menyatakan bahwa financial distress berpengaruh pada pergantian auditor. Namun hasil penelitian ini bertentangan dengan hasil penelitian yang dilakukan oleh Aprilia (2013), Kurniasari (2014), Yuka dan Rizal (2016) yang menyatakan kesulitan keuangan atau financial distress tidak mempengaruhi pergantian auditor.

Perusahaan yang mengalami kondisi keuangan yang tidak sehat dikhawatirkan akan mengalami kebangkrutan. Kesulitan keuangan dimulai ketika perusahaan tidak dapat memenuhi jadwal pembayaran atau ketika proyeksi arus kas mengindikasikan bahwa perusahaan tersebut akan segera tidak dapat memenuhi kewajibannya (Brigham dan Daves, 2003). Hasil penelitian ini menunjukkan bahwa ketika suatu perusahaan mengalami financial distress, perusahaan akan melakukan pergantian KAP.

Hal ini bisa disebabkan karena perusahaan sudah tidak lagi memiliki kemampuan untuk membayar biaya audit yang tinggi dimana kondisi perusahaan sedang tidak stabil pada saat mengalami financial distress. Perusahaan dengan tekanan finansial cenderung untuk menggantikan KAP kemudian beralih ke KAP baru yang bisa memberikan pelayanan audit dengan biaya yang tidak terlalu tinggi sehingga masih bisa di jangkau oleh perusahaan. Manajemen lebih cenderung untuk 
ISSN: 2302-8556

menghabiskan waktu yang lebih banyak yang dilakukan untuk menghindari kebangkrutan dan berusaha menampilkan pencapaian kinerjanya daripada membuat keputusan-keputusan untuk mengelola perusahaan yang lebih baik. Sehingga perusahaan yang mengalami financial distress biasanya akan menggunakan jasa auditor independen tinggi untuk meningkatkan kepercayaan shareholder, kreditor, dan juga untuk mengurangi resiko litigasi.

Hasil pengujian dengan menggunakan regresi logistik menunjukkan nilai koefisien positif sebesar 0,157 dengan tingkat signifikansi sebesar 0,449 yang lebih besar dari $\alpha=5 \%(0,449>0,05)$. Hal ini menunjukkan bahwa variabel audit fee tidak berpengaruh pada auditor switching dengan kata lain $\mathrm{H}_{2}$ ditolak. Hasil penelitian ini mendukung hasil penelitian Nur Ismaya (2017), Handini (2017) yang menyatakan bahwa audit fee tidak berpengaruh pada auditor switching. Di sisi lain penelitian ini bertentangan dengan hasil penelitian Astuti (2014), Pradhana (2015) yang menyatakan bahwa audit fee berpengaruh positif pada pergantian auditor.

Manajemen sebagai agent mempunyai fungsi decision making dan otoritas. Dalam hal ini apabila manajemen menganggap KAP yang dipilih sudah memenuhi kualifikasi yang dibutuhkan dan dapat sejalan dengan pandangan manajemen tersebut, penawaran audit fee yang relatif tinggi bukan merupakan suatu masalah sehingga perusahaan tidak melakukan auditor switching.

Jika dikaitkan dengan teori agensi yang mengasumsikan bahwa salah satu sifat agent adalah rasional. Rasional dalam hal ini yaitu membandingkan antara cost dan benefit, maka kondisi dimana manajemen memilih auditor dengan penawaran fee 
yang relatif tinggi namun auditor tersebut dapat sejalan dan memenuhi kualifikasi yang dibutuhkan. Hal ini dapat diartikan bahwa memberikan benefit yang lebih tinggi dari cost yang dikeluarkan, telah menggambarkan kebenaran asumsi tersebut

Hasil pengujian dengan menggunakan regresi logistik menunjukkan nilai koefisien positif sebesar 12,530 dengan tingkat signifikansi sebesar 0,348 yang lebih besar dari $\alpha=5 \%(0,348>0,05)$. Hal ini menunjukkan bahwa variabel reputasi auditor tidak mampu memoderasi pengaruh financial distress pada auditor switching. Hasil penelitian ini menunjukkan bahwa reputasi auditor tidak menyebabkan perusahaan untuk mengganti KAP. Hasil penelitian isi sependapat dengan penelitian Rahayu (2012) yang menunjukkan hasil bahwa variabel reputasi auditor tidak mampu memoderasi hubungan antara financial distress terhadap auditor switching.

Auditor yang berafiliasi dengan KAP Big Four atau tidak berafiliasi dengan KAP Big Four akan tetap memperhatikan kondisi financial distress dari perusahaan yang diaudit. Dengan demikian, manajemen akan beranggapan bahwa apapun reputasi auditor yang dipilih perusahaan, akan berpendapat yang sama terkait dengan financial distress perusahaan sehingga tidak harus melakukan auditor switching. Walaupun terjadi auditor switching itu disebabkan oleh peraturan mengenai rotasi auditor.

Hasil pengujian dengan menggunakan regresi logistik menunjukkan nilai koefisien positif sebesar 0,339 dengan tingkat signifikansi sebesar 0,671 yang lebih besar dari $\alpha=5 \%(0,671>0,05)$. Hal ini menunjukkan bahwa variabel reputasi auditor tidak mampu memoderasi pengaruh audit fee pada auditor switching. Hasil 
ISSN: 2302-8556

penelitian isi sependapat dengan penelitian Amalia (2015) yang menunjukkan hasil bahwa variabel reputasi tidak mampu memoderasi hubungan antara audit fee terhadap auditor switching.

Bagi para manajemen perusahaan cenderung memakai jasa KAP yang sudah memiliki reputasi tinggi hal itu sebagai pencitraan bagi perusahaan mereka. Manajemen menganggap KAP besar ataupun KAP kecil sama-sama mempunyai reputasi yang baik sehingga tidak perlu untuk melakukan auditor switching. Jadi, berapapun audit fee yang ditawarkan perusahaan oleh KAP besar ataupun KAP kecil selama dapat memberikan opini yang diharapkan manajemen perusahaan, maka tidak dilakukan auditor switching.

\section{SIMPULAN}

Berdasarkan hasil penelitian yang diperoleh melalui pengujian statistik serta pembahsan yang telah diuraikan pada bab-bab sebelumnya maka dapat disimpulkan bahwa: 1). Financial distress berpengaruh positif pada auditor switching. Hal ini berarti bahwa perusahaan yang mengalami financial distress cenderung untuk melakukan auditor switching dibandingkan dengan perusahaan yang tidak mengalami financial distress; 2). Audit fee tidak berpengaruh pada auditor switching. Hal ini berarti bahwa manajemen menganggap KAP yang dipilih sudah memenuhi kualifikasi yang dibutuhkan dan dapat sejalan dengan pandangan manajemen tersebut, penawaran audit fee yang relatif tinggi bukan merupakan suatu masalah sehingga perusahaan tidak melakukan auditor switching; 3). Reputasi Auditor tidak memoderasi pengaruh financial distress pada auditor switching. Hal ini berarti bahwa 
apapun reputasi auditor yang dipilih perusahaan, auditor akan berpendapat yang sama terkait dengan financial distress perusahaan sehingga tidak harus melakukan auditor switching; 4). Reputasi Auditor tidak memoderasi pengaruh audit fee pada auditor switching. Hal ini berarti bahwa berapapun audit fee yang ditawarkan perusahaan oleh KAP besar ataupun KAP kecil selama dapat memberikan opini yang diharapkan manajemen perusahaan, maka tidak dilakukan auditor switching.

Berdasarkan hasil analisis dan simpulan, dapat diajukan beberapa saran untuk peneliti selanjutnya dan untuk pihak-pihak yang berkepentingan sebagai berikut: 1). Keterbatasan dalam penelitian ini adalah periode pengamatan yang digunakan hanya terbatas lima tahun. Penelitian selanjutnya disarankan untuk menggunakan cakupan tahun pengamatan yang lebih panjang guna memperkuat hasil penelitian sehingga dapat diketahui apakah perusahaan melakukan auditor switching secara mandatory atau perusahaan melakukan auditor switching secara voluntary; 2). Penelitian ini menunjukkan nilai $\mathrm{R}$ Square sebesar 0,347 yang artinya variabel bebas yang digunakan dalam penelitian ini mempengaruhi variabel terikat sebesar $34,7 \%$ dan sekitar $65,3 \%$ dipengaruhi oleh variabel bebas. Penelitian selanjutnya, diharapkan dapat menyempurnakan penelitian ini dengan menambah variabel lain yang dapat mempengaruhi auditor switching; 3). Peneliti selanjutnya diharapkan memperhatikan professional fee atau honorarium tenaga ahli yang dibayarkan oleh klien untuk auditor. 
ISSN: 2302-8556

E-Jurnal Akuntansi Universitas Udayana

Vol.24.1.Juli (2018): 58-86

\section{REFERENSI}

Aprillia, Eka. 2013. Analisis Faktor-Faktor yang Mempengaruhi Auditor Switching. Accounting Analysis Journal, 2 (2).

Astrini, Novia Retno dan Dul Muid. 2013. Analisis Faktor-Faktor yang Mempengaruhi Perusahaan Melakukan Auditor Switching Secara Voluntary. Diponegoro Journal of Accounting, 2 (3), Hal.1-11.

Astuti, Ni Luh Putu Paramita \& I Wayan Ramantha. 2014. Pengaruh Audit Fee, Opini Going Concern, Financial Distress dan Ukuran Perusahaan pada Pergantian Auditor. Jurnal Akuntansi Universitas Udayana, 7 (3), Hal.663-676.

Beaver, W.H, Maria Correia, Maureen F. McNichols. 2011. Financial Statment Analysis and The Prediction of Financial Distress. Foundations and Trends in Accounting, 5 (2), Hal.99-173.

Chadegani, Arezoo Aghaei, Zakiah Muhammaddun Mohamed, Azam Jari. 2011. The Determinant Factors of Auditor Switch among Companies Listed on Tehran Stock Exchange. International Research Journal of Finance and Economics. ISSN 1450-2887 Issue 80.

Crasswell, A.T. 1998. The Assosiation between qualified opinion and auditor switches. Journal Accounting and Business Research. Edisi 19. Hal. 23-31.

Damayanti, S. dan M. Sudarma. 2007. Faktor-Faktor yang Mempengaruhi Perusahaan Berpindah Kantor Akuntan Publik. Simposium Nasional Akuntansi 11, Pontianak.

Davis, L.R., Soo, B., \& Trompeter, G. 2007. Auditor Tenure and Ability to Meet or Beat Earning Forecast. Journal of Finance and Economics.

Dwijayanti, R. Meike Erika dan Arifin Sabeni. 2014. Faktor-Faktor Yang Mempengaruhi Auditor Switching Secara Voluntary. Diponegoro Journal Of Accounting, 3 (3), Hal.1-8.

Faradila, Yuka dan M Rizal Yahya. 2016. Pengaruh Opini Audit, Financial Distress, Dan Pertumbuhan Perusahaan Klien Terhadap Auditor Switching (Studi Pada Perusahaan Manufaktur Yang Terdaftar Di Bursa Efek Indonesia Tahun 2010- 
2014). Jurnal Ilmiah Mahasiswa Ekonomi Akuntansi (JIMEKA), 1 (1), Hal.81100.

Gamal, Walid EL. 2012. Determinants of audit fees: Evidence from Lebanon. International Jouurnal Business Research, 5 (11).

Ghozali, Imam, 2012. Aplikasi Analisis Multivariate dengan Program SPSS. Semarang: Badan Penerbit Universitas Diponegoro.

Halim, A. 1997. Dasar- Dasar Audit Keuangan. Yogyakarta: Unit Penerbitan dan Percetakan (UPP) AMP YKPN.

Handini, Ulfi Yulia Mutiara. Pengaruh Audit Fee, Opini Going Concern, Financial Distress, Ukuran Perusahaan Klien, Kepemilikan Institusional, dan Kompleksitas Perusahaan Terhadap Auditor Switching. Skripsi Universitas Muhammadiyah Surakarta.

Harum Diandika, Kadek. 2017. Financial Distress Sebagai Pemoderasi Pengaruh Fee Audit pada Auditor Switching. E-Jurnal Akuntansi Universitas Udayana, 18 (1), hal 246-275.

Ismail, Shahnaz, Huson Joher Aliahmed, Annuar Md. Nassir, Mohamad Ali Abdul Hamid. 2008. Why Malaysian Second Board Companies Switch Auditors. Evidence of Bursa Malaysia. International Research Journal of Finance and Economics. Issue 13.

Ismaya, Nur. 2017. Pengaruh Opini Audit, Pergantian Manajemen, Ukuran Kap, Ukuran Perusahaan Klien dan Audit Fee Terhadap Auditor Switching pada Perusahaan Jasa yang Terdaftar Di BEI Tahun 2010-2015. Skripsi Institut Agama Islam Negeri Surakarta

Jensen, M.C. dan W. H. Meckling. 1976. Theory of the Firm: Managerial Behaviour, Agency Cost and Capital Structure. Journal of Financial Economics, 3 (4), pp. 305-360.

Kurniasari, Desi. 2014. Faktor-Faktor Terkait Kap Switching Yang Dilakukan Perusahaan Secara Voluntary (Studi Empiris Pada Perusahaan Industri Barang Konsumsi di Bursa Efek Indonesia Periode 2008-2012). Jurnal fakultas ekonomi dan bisnis. Universitas Dian Nuswantoro Semarang. 
Lestari, Hana Puji. 2012. Faktor-Faktor yang Mempengaruhi Perusahaan Manufaktur Terdaftar di BEI Melakukan Voluntary Auditor Switching. Skripsi Universitas Diponegoro, Semarang.

Mahantara. A.A Gede Widya. 2013. Faktor-Faktor yang Memengaruhi Pergantian Kantor Akuntan Publik pada Perusahaan yang Terdaftar di Bursa Efek Indonesia. Tesis. Universitas Udayana, Denpasar.

Mardiyah, A.A. 2002. Pengaruh Faktor Klien dan Faktor Auditor terhadap Auditor Changes: Sebuah Pendekatan dengan Model Kontinjensi RPA (Recursive Model Algorithm). Media Riset Akuntansi, Auditing dan Informasi, 3 (2), Hal.133-154.

Nabila. 2011. Faktor-faktor yang mempengaruhi auditor switching. Skripsi Akuntansi Fakultas Ekonomi Universitas Diponegoro, Semarang.

Nasser, Wahid, Nazri, dan Hudaib, 2006. Auditor-Client Relationship : The Case of Audit Tenure and Auditor Switching in Malaysia. Managerial Auditing Journal , 21 (7), pp. 724-737.

Pawitri, Ni Made Puspa dan Ketut Yadnyanya. 2015. Pengaruh Audit Delay, Opini Audit, Reputasi Auditor dan Pergantian Manajemen pada Voluntary Auditor Switching. E-jurnal Akuntansi Universitas Udayana, 10 (1), Hal.214-228.

Pradhana, Made Aditya Bayu dan I.D.G. Dharma Suputra. 2015. Pengaruh Audit Fee, Going Concern, Financial Distress, Ukuran Perusahaan, Pergantian Manajemen Pada Pergantian Auditor. E-Jurnal Akuntansi Universitas Udayana, 11 (3), Hal.713-729.

Praptitorini, Mirna Dyah dan Januarti Indira. 2007. Analisis Pengaruh Kualitas Audit, Debt Default dan Opinion Shopping Terhadap Penerimaan Opini Going Concern. Simposium Nasional Akuntansi X. Universitas Hasanudin. Makasar.

Rahayu, Santi. 2012. Moderasi Reputasi Auditor terhadap Faktor-Faktor yang Mempengaruhi Auditor Switching pada Perusahaan Industry Manufaktur yang Terdaftar di BEI pada Tahun 2006-2010. Tesis. Universitas Esa Unggul, Jakarta. 
Schwartz, K.B. dan B.S. Soo. 1995. An Analysis of Firm 8-K Disclousure of Auditor Changes by Firms Approaching Bankruptcy, Auditing: A Journal of Practice Theory, 14 (1), pp: 125-135.

Sinarwati, Ni Kadek. 2010. Mengapa Perusahaan Manufaktur yang Terdaftar di BEI Melakukan Pergantian Kantor Akuntan Publik?. Simposium Nasional Akuntansi XIII Purwokerto.

Smith, D.B. dan D.R. Nichlos (Oct, 1982). A Market Reaction Test of Investor Reaction to Clients Auditors disagreement. Journal of Acoounting and Economics, pp 109- 120.

Sugiyono. 2014. Metode Penelitian Bisnis. Bandung: CV Alfabeta.

Sulistiarini, Endina, dan Sudarno. 2012. Analisis Faktor-Faktor Pergantian Kantor Akuntan Publik (Studi Empiris Pada Perusahaan Manufaktur di Bursa Efek Indonesia Periode 2006-2010). Diponegoro Journal Of Accounting, 1 (2), Hal.1-12.

Suparlan dan Andayani Wryan.2010. Analisis Empiris Pergantian Kantor Akuntan Publik setelah ada kewajiban Rotasi Audit. SNA XIII 2010. Purwakarta.

Suyono, Eko, Yi, Feng and Riswan. (2013). Determinant Factors Affecting The Auditor Switching: An Indonesian Case. Global Review of Accounting and Finance, 4(2), Hal.103-116.

Utami, Suci Rismanda. 2013. Pengaruh Opini Audit, Ukuran KAP, Ukuran Perusahaan Klien, dan Financial Distress terhadap Auditor Switching (Studi Empiris pada Perusahaan Manufaktur yang Terdaftar di Bursa Efek Indonesia Tahun 2008-2012). Jurnal Akuntansi Fakultas Ekonomi dan Bisnis Universitas Hasanuddin, Makasar.

Wea, Alexandros Ngala Solo dan Dewi Murdiawati. 2015. Faktor-Faktor Yang Mempengaruhi Auditor Switching Secara Voluntary Pada Perusahaan Manufaktur. Jurnal Bisnis dan Ekonomi (JBE), 22 (2), Hal.154-170.

Widyanti, A.A. Sagung Istri Agung dan I Dewa Nyoman Badera. 2015. Reputasi Auditor Sebagai Pemoderasi Pengaruh Financial Distress pada Auditor 
ISSN: 2302-8556

Switching. Skripsi Sarjana Jurusan Akuntansi pada Fakultas Ekonomi dan Bisnis Universitas Udayana, Bali.

Wijaya, Edwin. 2015. Pengaruh Audit Fee, Opini Going Concern, Financial Distress, Ukuran Perusahaan, dan Ukuran KAP pada Pergantian Auditor Perusahaan Manufaktur yang Terdaftar di Bursa Efek Indonesia Periode 2008-2013. Skripsi Universitas Udayana.

Wijayani, Evy Dwi. 2011. Analisis Faktor-faktor yang mempengaruhi Perusahaan di Indonesia Melakukan Auditor Switching. Skripsi Universitas Diponegoro. Semarang.

Wulan Indah Sari, Ika. 2016. Reputasi Auditor Sebagai Pemoderasi Pengaruh Audit Fee pada Auditor Switching. Skripsi Sarjana Jurusan Akuntansi pada Fakultas Ekonomi dan Bisnis Universitas Udayana, Bali

Yu, Dong Michael. 2007. The Effect of Big Four Office Size on Audit Quality. Journal Faculty of the Graduate School at the University of Missouri: Columbia. 